the field was due to an attempt to discover whether Laue's effects were caused by the $\mathrm{X}$-rays themselves (as corpuscular) or by electromagnetic wave-radiation associated with corpuscular rays. W. L. Bragg, then a student at Cambridge, was soon able to show that the zinc blende pattern of spots was due to the symmetry of the crystal, and not to the character of an X-ray spectrum; and he followed it up by determining the actual arrangement of the atoms in the still simpler cubic crystals of potassium and sodium chlorides. Sir William Bragg then found that the reflected $\mathrm{X}$-rays, when analysed by an ionization spectrometer, consisted both of a general (continuous) spectrum and of rays of characteristic wave-lengths (Barkla's $K$ and $L$ rays), and that indeed Laue's explanation of the effect as a diffraction of electromagnetic waves must be accepted.

Moseley's brilliant measurement of the wave-lengths or frequencies of the characteristic $X$-radiations of the various elements immediately followed, and their relations were shown to offer a complete explana. tion of the Periodic Law of the elements; and the sequence number (atomic number) of the element suddenly developed a wonderful and unanticipated meaning, in expressing the positive charge on the nucleus of the atom, and the number of the surrounding planetary negative electrons. By a combin. ation of the use of the Laue photographic method and the Bragg ionization spectrometer, together with the Debye powder method when good crystals are not available, and the rotating methods more lately introduced, all the important subsequent progress in unravelling the internal structure of crystals, not only of very simple substances but also of many complicated ones, including organic substances containing a large number of atoms in the molecule, has been achieved.

In their article Sir William and Prof. Bragg scarcely do justice to the really great progress which had been made in crystallography previous to 1912. They state that "at that time crystallography was so much a science apart, and played so little part in physics and chemistry, that the idea of a crystal pattern had never presented itself to the majority of scientists". If this were really the case it was the fault of workers in other scientific fields; for a small band of devoted crystallographers were insistently, in season and out of season, directing attention to the subject, and to its immense importance to physicists and chemists.

My own "Crystallography and Practical Crystal Measurement" set it forth clearly in the year 1911. The Laue discovery came at the most psychologically appropriate moment, to clinch the facts, to arouse universal interest in the subject, to reveal the 230 types of crystal structure already specified and defined by the genius of Barlow in Great Britain and simultaneously and independently by Schoenflies and Fedorow on the Continent, as real entities and not merely the natural deductions from all the accumulated experimental work on crystals, and to add that to crystallographic knowledge which rendered it assured and incontrovertible.

Sufficient will have been said to indicate the value of this Laue special number of Current science, and it is with all sincerity that we congratulate our Indian scientific colleagues in so admirable a produc. tion. In the preface, it is foreshadowed that other special numbers are being prepared, on canal rays, genetics, and on animal development, and among the articles in the first mentioned we are promised contributions by Sir J. J. Thomson, Dr. F. W. Aston, and Dr. J. D. Cockeroft. We shall look forward to these further special numbers with all the greater interest, from the pleasure which the perusal of the present issue commemorating the initiation of Laue diagrams has afforded us.
A. E. H. TutTon.

\title{
The Chemical Research Institute, Warsaw
}

\begin{abstract}
$\mathrm{T}$ HE Chemical Research Institute of Warsaw (Chemiczny Instytut Badawczy w Warszawie) was founded by Prof. Ignacy Mościcki, who is now President of Poland. Firm in his conviction that the independence of Poland would be restored and that the country would then need the services of such an institute, Prof. Mościcki took the first steps to realize this aim during the Great War, in 1916. $\mathrm{He}$ founded the Metan Company in Lwów, the object of which was to carry out chemical research for industry. The shareholders of the Metan Company voluntarily resigned from their material interests in this organization in 1922, and transformed it into the Chemical Research Institute Association, which pays out no dividends, in accordance with its by-laws, and expends all revenue and earnings on the prosecution of new research work. Having thus arisen without the help of the Government or of industry, the Institute was in 1925 transferred to Warsaw, where it has since 1927 occupied its own commodious, modern building, erected thanks to the donations of Poles, both at home and abroad. The building was officially declared open in 1928 by Prof. Mościcki, who had in the meantime been elected President of the Republic. The Institute contains a Department of Inorganic Industry, a Coal Research Department,
\end{abstract}

an Analytical Department, an Alcohol Research Department, a Department of Rubber Synthesis, etc.

The personnel of the Institute at present numbers 161. The director is Prof. Kazimierz Kling, on $\Theta$ of the co-founders of the Metan Company. The other members of the executive board are : Prof. Wojciech Switeosławski (at present Minister of Education), Prof. Jan Czochralski, Prof. Wacław Lesnianski, Mr. Jerzy Pfanhauser, Miss Halina Starczewska and Mr. Zdzistaw Zaleski. The chairman of the Board of Curators is Mr. Eugeniusz Kwiatkowski, the present vice-premier and Minister of Finance.

The Institute is engaged in tracing out the lines of the technical progress of the chemical industry of Poland, with special reference to the possibilities of extending the use of and improving Polish raw materials on one hand and of substituting imported raw materials by home-produced ones on the other.

The research work conducted by the Institute is chiefly concerned with petroleum, natural gas, sulphuric acid, aluminium, the analysis and standardization of coal, metallurgical coke and rubber. The twentieth anniversary of the foundation of the Institute was celebrated in the Warsaw Polytechnic on December 9, the president of the Republic of Poland being present. 